\title{
Does the Writing Argumentative Text Ability Correlate to Writing Motivation and Grammatical Competence?
}

\author{
Asep Muhyidin, Dase Erwin Juansah, Ediwarman, Aisyah Hamidiyah \\ University of Sultan Ageng Tirtayasa \\ muhyidin21@untirta.ac.id
}

\begin{abstract}
This research focused on the ability of writing argumentative text correlate to writing motivation and grammatical competence. This research used survey method through correlational study. It was conducted on the students of grade $X$ in SMA Negeri 3 Serang in academic year 2016/2017 using simple random sampling technique. The data collection in this research were tests to get the data of writing argumentation ability and grammatical competence, while the questionnaire with Likert scale is used to get the data of students' writing motivation. The collected data were analyzed descriptively and inferentially. The data was analyzed using SPSS program version 22.00. Prior to hypothesis testing, several requirements were done: 1) normality test by using Lilliefors technique, 2) linearity test using $F$ test; and 3) correlation test of product moment correlation from Pearson. The results prove: 1) the correlation coefficient (rxly) shows that the $r_{\text {count }}$ is higher than the $r_{\text {table }}(0.585>0.245)$. Therefore the first hypothesis is accepted; 2$)$ the correlation coefficient (rx2y) shows that the $r_{\text {count }}$ is higher than the $r_{\text {table }}(0.786>0.245)$. This means that the second hypothesis is accepted; and 3) the Fcount coefficient 9,421> $F_{\text {table }} 4.07$. Based on the test results, Pvalue 0.000 is lower than 0.05. The conclusion is that the motivation of writing $\left(X_{1}\right)$ and grammatical competence $\left(X_{2}\right)$ has a positive and significant relationship with the ability to write argumentative text $(Y)$.
\end{abstract}

Keywords-writing argumentative text; writing motivation; and grammatical competence

\section{INTRODUCTION}

Indonesian language teaching in the 2013 curriculum is essentially teaching language skills, not teaching Indonesian language. The language skills that need to be emphasized in teaching Indonesian language are receptive skills and productive skills. Language teaching begins with the teaching of receptive skills, while productive skills can be enhanced in the next stage. The improvement of the two skills will unite as an integrated language activity. Therefore, the scope of Indonesian learning includes four aspects, namely: 1) listening, 2) speaking, (3) reading, and (4) writing.

Writing is one of the most essential language skills to be mastered by high school students, including in this case, the ability to write argumentative texts (Alwasilah and Alwasilah, 2005, p.116) state that an argumentation is a composition proving the truth or untruth of a statement. The text of argumentation is a writing aimed at convincing or influencing the reader by way of expressing the reason and strong evidence of a truth. The argumentative text is one of the persuasive forms that serve to convince others through clear reasons and good evidence that a certain value or point of view should be taken (Ridhani, 2013). The ability to write argumentative texts is the ability of the author to put his ideas in order to convince or influence the reader by way of conveying several reasons and strong evidence for a truth, statement or subject matter.

Iskandarwassid and Sunendar (2008, p.248) state that compared to the other three language skills, writing skill is more difficult to master even native speakers of the language. Writing is the most complex language skill. Unlike the spoken language, in written language there is a procedure of writing (spelling) in addition to aspects of grammar and vocabulary. In other words, in written language, the writer is required to pay attention to the completeness of the elements of grammar such as the form of words or sentence arrangements, the accuracy of the word choice, the use of spelling, and the use of punctuation in expressing ideas.

Based on the author's observation, the ability to write argumentative text of the students of grade X SMAN 3 Serang was far from what is expected. The lack of ability was seen in: 1) the inability of students to organize ideas with logical and systematic thought; 2) the inability of students to express their ideas into Indonesian expression according to the rules; 3) the inability of students to write the results of their writing in accordance with the General Guidelines for Indonesian Spelling (PUEBI); and 4) the inability of students to choose the variety of Indonesian language in accordance with the communication context.

Referring to the above description, the mastery of language rules requires good grammatical competence. Grammatical competence is an important element in determining the quality of students' argumentative text writing skills. Grammar according to Kridalaksana (2010, p.66) is a subsystem in the organization of a language in which its linguistic 
units structured to form larger units. Meanwhile, Brown (2000, p.199) defines the term grammatical competence is the ability of language, especially in the phrase sentence. Therefore, it can be concluded that grammatical competence is the ability of students in mastering the rules of a language system that includes phonology, morphology, syntax, and semantics.

In addition to grammatical competence factors, other factors cause students difficulty in writing argumentative text is lack of motivation as they were always given the task by the teacher. Motivation is a conscious effort to activate, direct, and maintain a person's behavior to be encouraged to act, to do something, to achieve a certain result or goal (Purwanto, 2005 , p.73). Motivation is very influential in achieving goals. Vlodkoski (in Suciati, 1997, p.41) states that motivation is a condition that causes or cultivates a certain behavior and that will give direction and resilience to the behavior.

Students who write argumentative text with good writing motivation will generate the text of argumentative text by obeying the rules of the correct Indonesian language. Good writing motivation will lead to write well argumentation. The students will choose the appropriate diction (word choice) to determine the accuracy of the selected word. In addition, they will aware of the structure of the sentence thus an effective sentence is built. Completeness of sentence structure will also a major concern. A sentence can be said complete if it has a minimum sentence structure of the subject and predicate. Therefore, writers who have good motivation always do an evaluation of the writing, whether the sentence is complete or not by paying attention to the subject and predicate.

Research on the ability of writing argumentative text was done by Yi and Ni (2015) in high school in Nanjing, China, Saputra (2016) conducted research on the ability to write argumentation at high school Indonesia, and Khodabandeh et al. (2013) conducted research on writing an argument essay in the second grade of high school in Iran. Subsequently Lap and Truc (2014) conducted research on an argumentation essay at the second level of English teacher training school in Vietnam. This research will be focused on writing argumentation skills related to writing motivation and grammatical competence. Therefore, the researcher is interested to conduct research on the students of grade X SMA Negeri 3 Serang City academic year 2016/2017 to test whether there is a correlation between writing motivation and grammatical competence with the ability to write argumentative text,.

\section{METHODS}

The research method used in this research is survey method through correlational study. According to Emzir (2010, p.37) correlational research describes a general approach to research that focuses on assessing the co-variations among naturally occurring variables. The purpose of correlational research is to identify predictive relationships using correlation techniques. Correlational research was chosen in this research was based on the consideration that the purpose of this study was designed to obtain information relating to the status of symptoms at the time of the study. Another consideration was because through correlational studies, the extent to which variations in a factor relate to variations in one or more other factors based on the correlation coefficient could be detected, as well as to test the hypothesis.

This research was conducted on the students of class X in SMAN 3 Serang academic year 2016/2017. The population of this study was the students of class X SMAN 3 Serang in the even semester of the academic year 2016/2017. The total number of students in grade X was 439 students. The sample of the research was 44 students spread from class $\mathrm{X}$ 1 to $\mathrm{X}-11$ taken by simple random sampling technique.

The test as instrument was used to get the data of writing argumentation and grammatical competence, while the questionnaire with Likert scale was used to get the students' writing motivation data. Data on the ability to write argumentative text was collected using compositional tests. Each student was required to write an argumentative text according to a determined theme. Then the assessment of test results referred to the components in the grid that include: 1) the content of writing; 2) writing organization; 3) the use of reasoning; 4) use of spelling; and 5) writing techniques. Grammatical competence data were collected using a standard multiple-choice test. The test referred to: 1) phonological rules; 2) morphological rules; 3) syntactic rules; and 4) semantic rules. Questionnaires of writing motivation were collected according to indicators including: 1) attention; 2) relevance; 3) confident; and 4) satisfaction.

The collected data were analyzed descriptively and inferentially. Descriptive analysis consists of presenting data with histogram. Inferential analysis (hypothesis test) using simple regression and correlation analysis for first and second hypothesis while for the third hypothesis using multiple regression and correlation analysis. Prior to hypothesis testing, the first test of data analysis requirements were: 1) normality test by using Lilliefors technique, the interpretation criterion if the Kolmogorov-Smirnov coefficient has significant $(\mathrm{P})$ greater than 0.05 , then the data is normally distributed. Conversely, if the significance less than 0.05 , then the data is not normally distributed; 2) linearity test using $\mathrm{F}_{\text {test }}$; and 3 ) correlation test used product moment correlation from Pearson. The data that has been collected was analyzed through several stages. The hypothesis was tested using bivariate analysis and regression analysis. This analysis was useful to know the influence between free variable and dependent variable. This analysis uses product moment formula using SPSS version 22.00 . 


\section{Description of Research Data}

\section{FINDING AND DISCUSSION}

Writing motivation data $\left(\mathrm{X}_{1}\right)$ is a score obtained through questionnaire writing instruments. Based on the calculation results, the highest value was 92 and the lowest value 61 . The score were: mean score 78.28, median 77, mode 77, and standard deviation 8.77. The tendency of variable value $\mathrm{X}_{1}$ was divided into three: high, medium, and low. Writing motivation data showed that 11 students $(25 \%)$ were in high category, 25 students $(57 \%)$ were in medium category, and 8 students $(18 \%)$ were in low category.

The grammatical competence data was the value obtained through objective tests. The highest score from the data was 90 and the lowest was. The mean for the score was (average) 74.50; median was 77; with a standard deviation were 10.97, and modus was 70. The grammatical competence data indicates that 3 students (7\%) were in the high category, 31 students $(70 \%)$ are in moedium category, and 10 students $(23 \%)$ were in the low category.

The data of argumentative text writing ability was obtained through a writing composition test instrument. The data gained were: the highest score was 81 and the lowest score was 58. The mean was 74,20; the median was 75; with standard deviation 7.61, and the mode was 64 . The distribution of the argumentative writing ability showed that there were 9 students $(20 \%)$ were in high category, 26 students $(60 \%)$ were in medium category, and 9 students $(20 \%)$ were in low category.

Prior to hypothesis testing, testing the requirements of data analysis was done. Normality testing of writing motivation data $\left(X_{1}\right)$ resulted a maximum Lo of 0.018 . From the list of critical values $L$ for the Lilliefors test with $n=44$ and the real level $\alpha=0.05$ obtained $\mathrm{L}_{\mathrm{t}}=0.130$. From the above comparison it appeared that Lo is smaller than $\mathrm{L}_{\mathrm{t}}$, thus it can be concluded that writing motivation data $\left(\mathrm{X}_{1}\right)$ came from a normally distributed population.

Normality test of grammatical competence data $\left(\mathrm{X}_{2}\right)$ resulted a maximum $\mathrm{L}_{\mathrm{o}}$ of 0.031 . From the list of critical values $\mathrm{L}$ for the Lilliefors test with $\mathrm{n}=44$ and the real level $\alpha=0.05$ obtained $\mathrm{L}_{\mathrm{t}}=0.130$. From the above comparison it appeared that Lo was smaller than $\mathrm{L}_{\mathrm{t}}$, so it can be concluded that the grammatical competence data $\left(\mathrm{X}_{2}\right)$ came from a normally distributed population.

The results of the above linearity test showed that $\mathrm{F}_{\text {count }}>\mathrm{F}_{\text {table }}$ was on writing motivation variable $(1,102>0,424)$ and significance equal to $0,000<0,05$, whereas at grammatical competence $(1,156>0,355)$ and significance $0,000<0,05$, so both variables can be said to be linear.

The multicollinearity test was intended to know the presence or absence of multicollinearity among independent variables. The multicollinearity test required that between independent variables there should not high correlation, i.e. the value of $r_{\text {coun }} t$ is higher than 0.800 . Multicollinearity was tested using product moment correlation to calculate correlation among independent variables. The multicollinearity test was done as a requirement for the correlation analysis of Product Moment from Karl Person.

Based on multicollinearity test results between variables, the intercorrelation between variables was 0.692 . It can be concluded that the intercorrelation result between the independent variables did not exceed 0.800 . Thus there was no multicollinearity, it means that multiple correlation analysis can be used.

\section{The Correlation between Writing Motivation and Writing Ability of Student's Argumentative Text}

The results of statistical calculations using product moment correlation analysis of Karl Person using SPSS program version 22.00 showed that the coefficient of correlation $\left(\mathrm{rx}_{1} \mathrm{y}\right)$ writing motivation with the ability to write argumentative text students X class SMAN 3 Serang academic year 2016/2017 was 0.586. To determine whether the effect is significant or not, the value of $r_{\text {count }}$ with the $r_{\text {table }}$ at the $5 \%$ error level and $n=44$ was compared and the result was 0.245 . The result of correlation coefficient $\left(\mathrm{rx}_{1} \mathrm{y}\right)$ shows that $\mathrm{r}_{\text {count }}$ was bigger than $\mathrm{r}_{\text {tabel }}(0,585>0,245)$ hence there was significant relation. Thus the proposed hypothesis was accepted. Therefore, the results of this study proved the first hypothesis that there was a positive and significant correlation between the motivation of writing with the ability to write argumentative text in grade $\mathrm{X}$ students SMAN 3 Serang.

The result of the calculation through the categorization formula was found out that the level of writing motivation of the 11 students (25\%) were considered in the high category, 25 students $(57 \%)$ were in medium category, and 8 students $(18 \%)$ were in the low category. It can be concluded that the tendency of writing motivation variable was considered in the medium category.

High writing motivation will make students able to write well because writing activity depends on the motivation of the writer. Students will write to realize the goals desired by it. One of the goals of students' writing is to express themselves to others. Inner motivation will make writing better although writing includes complex activities. This is because writing combines a variety of mastery including orthography, graphology, and linguistic aspects such as semantics, syntax, spelling, and written conventions (Panahandeh and Asl, 2014). 


\section{Relation of Grammatical Competence with Writing Capability of Student Argumentation}

The second hypothesis states that there was a positive and significant correlation between grammatical competences $\left(\mathrm{X}_{2}\right)$ with writing argumentative text ability $(\mathrm{Y})$ students of grade X SMA Negeri 3 Serang academic year 2016/2017. Testing was done using correlation between the $r_{\text {count }}$ with the $r_{\text {table }}$ at $5 \%$ error level. If the value of $r_{\text {count }}$ was higher than the $r_{\text {table }}$ then the correlation was significant, otherwise if the value of $r_{\text {count }}$ is lower than the $r_{\text {table }}$ then the correlation was not significant. Simple data processing using SPSS program version 22.00 showed that the correlation coefficient $\left(\mathrm{rx}_{2} \mathrm{y}\right)$ grammatical competence $\left(\mathrm{X}_{2}\right)$ with the ability to write argumentative text $(\mathrm{Y})$ was 0.786 . To determine whether the effect was significant or not, the $r_{\text {count }}$ with the $r_{\text {table }}$ at the $5 \%$ error level and $n=44$ at 0.245 was compared. Result of correlation coefficient $\left(\mathrm{rx}_{2} \mathrm{y}\right)$ shows that $\mathrm{r}_{\text {count }}$ was higher than $\mathrm{r}_{\text {table }}(0,786>0,245)$ hence there was significant relation. Thus the proposed hypothesis was accepted. Therefore, the result of the study is there was a positive and significant correlation between grammatical competence and the writing argumentative text ability of grade X students of SMA Negeri 3 Serang. This implies that the better the grammatical competence, the better the writing argumentative text ability.

Based on the result of the research, grammatical competence shows that 3 students (7\%) were in high category, 31 students $(70 \%)$ are in medium category, and 10 students $(23 \%)$ were in low category. Grammatical competence is essentially a person's understanding and mastery of a part of the language aspects, or part of knowledge of the language system. Therefore, in general, people with good grammatical competence tend to have good language skills or language use, including in their argumentation writing skills. Grammatical competence and language skills included in this case writing, very closely related (Millrood, 2014)

\section{Relationship Motivation Writing and Grammatical Competence Together with Writing Capabilities Argumentative text}

The third hypothesis is that there was a positive and significant correlation between writing motivation $\left(\mathrm{X}_{1}\right)$ and grammatical competence $\left(\mathrm{X}_{2}\right)$ with the argumentative text writing ability $(\mathrm{Y})$ in grade $\mathrm{X}$ SMAN 3 Serang academic year 2016/2017. Multiple correlation analysis was used to test this hypothesis. This test aimed at finding out the significant correlation of writing motivation $\left(\mathrm{X}_{1}\right)$ and grammatical competence $\left(\mathrm{X}_{2}\right)$ with the argumentative text writing ability $(\mathrm{Y})$. $\mathrm{F}_{\text {test }}$ was used to test the significance. The test result showed the $F_{\text {count }}$ was 9,421 while the $F_{\text {table }}$ is 4.07 . Based on the test obtained, $\mathrm{P}$ value was 0.000 lower than 0.05 . The conclusion is that the writing motivation $\left(\mathrm{X}_{1}\right)$ and grammatical competence $\left(\mathrm{X}_{2}\right)$ has a positive and significant relationship together with the argumentative text writing ability $(\mathrm{Y})$. From the above description it shows that grammatical competence gave more contribution to the argumentative text writing ability than writing motivation. That is, students' ability in writing argumentative text was strongly influenced by grammatical competence. This means that if students have good grammatical competence, the ability to write argumentative text will be good too. Nevertheless, both made a meaningful contribution. It shows that those three had strong correlation.

In this research, the best possible preparation was made by using scientific method. However, due to the limited ability of the researchers who were not supported by the expertise in the research and how to use the method, there was no possibility of mistakes in the results of this study. Therefore, some limitations of the research should be unveiled. First, the results of this study only revealed the ability to write the text of students' argumentation related to the variable of writing motivation and grammatical competence with the limited population in the students of grade X SMAN 3 Serang. Therefore, generalization of research conclusions can only be used against populations that have the same criteria and characteristics.

Secondly, as a survey study that collected data partially using a Likert scale questionnaire model, such as a research instrument that measures writing motivation, such research instruments are less able to reach the qualitative aspects of the indicators measured. This is understandable, because the data obtained from the respondents by self-report as the questionnaire has limitations. In this case it causes the respondent's tendency to choose a "good" answer/response alternative to the items provided. To overcome this, in fact has been attempted by researchers by calling on respondents to provide honest answers to each item statement. Third, the instrument is not a standard instrument, but made by the researchers themselves. Then to know the validity and reliability tested the instrument. Thus there are still many possible indicators that are not accommodated in the instruments.

\section{CONCLUSION}

Based on the results of research and discussion can be concluded that: 1) there was a positive and significant relationship between writing motivation and the ability to write argumentative text;2) there was a positive and significant relationship between grammatical competence with the ability to write the argumentative text of students; and 3) writing motivation $\left(\mathrm{X}_{1}\right)$ and grammatical competence $\left(\mathrm{X}_{2}\right)$ had a positive and significant correlation in line with argumentative text writing ability $(\mathrm{Y})$. High writing motivation made students able to write well because writing activity depended on the 
motivation of the writer. Students wrote to achieve goals. When the students' grammatical competence was good, the language skills or the use of language tended to be good, including their argumentation writing skills. From the results of the study, it appeared that grammatical competence gave high contribution to the ability to write argumentative text than writing motivation. That is, students' ability in writing argumentative text was strongly influenced by grammatical competence. This gave the reason that if students have good grammatical competence then the ability to write argumentative text will be good too. Nevertheless, both made a meaningful contribution. It shows that both the correlation between grammatical competence and the argumentative text writing ability as well as the correlation between writing motivation and the ability to write strong argumentative text.

\section{References}

Alwasilah, A. Chaedar \& Senny S. Alwasilah. (2005). Pokoknya menulis. Bandung: PT Kiblat.

Brown, H. D. (2000). Principles of languages learning and teaching. New York: Longman Inc.

Emzir. (2010). Metodologi penelitian pendidikan: Kuantitatif dan kualitatif. Jakarta: Raja Grafindo Persada.

Iskandarwassid \& D. Sunendar. (2008). Strategi pembelajaran bahasa. Bandung: Rosdakarya.

Khodabandeh, F., et.al. (2013). The impact of explicit, implicit, and no-formal genre-based instruction on argumentative essay writing. The Linguistic Journal, 7(1), 134-157.

Kridalaksana, Harimurti. (2009). Kamus linguistik. Jakarta: Gramedia Pustaka Utama.

Lap, Trinh Quoc dan Nguyen ThanhTruc. (2014). Enchancing vietnamese learners' ability in writing argumentative essays. The Journal of Asia TEFL, 11 (2), 63-91.

Millrood, R. (2014). Cognitive models of grammatical competence of students.The XXV Annual International Academic Conference, Language and Culture, 20-22 October 2014, 259-262. Retrieved from http://www.sciencedirect.com

Panahandeh, E., \& Shahran Esfandiari Asl. (2014). The effect of planning and monitoring as metacognitive strategies on iranian efl learners' argumentative writing accuracy. Procedia: Social and Behavioral Science, 98, 1409-1416. Retrieved from http://www.sciencedirect.com

Purwanto, N. (2005). Psikologi pendidikan. Bandung: PT. RemajaRosdakarya.

Ridhani, A. (2013). Tipe argumen wacana argumentasi tulis siswa sekolah dasar kelas tinggi. Jurnal Litera, 12 (1), 146158.

Saputra, D. S. (2016). Pengaruh metode pembelajaran dan berpikir kritis terhadap kemampuan menulis argumentasi. Jurnal Pendidikan Dasar, 7(1), 1-12.

Suciati. (1997). Teori motivasi. Jakarta: Depdikbud.

Yi, B., \& C. Ni. (2015). Planning and working memory effects on 12 performance in chinese efl learners' argumentative writing. Indonesian Journal of Applied Linguistics, 5(1), 44-53. 